
В ПРАВОСЛАВНОЙ ВОСКРЕСНОЙ ШКОЛЕ

Саратовский национальный исследовательский государственный университет

им. Н.Г. Чернышевского,

ул. Астраханская, 83, Саратов, 410012, Россия

ufim75@mail.ru

\begin{abstract}
Аннотация. Статья посвящена анализу социальных практик современного православного воскресного церковно-приходского образования Русской Православной Церкви (РПЦ). Представлена краткая историография православного церковно-приходского воскресного образования в России. Рассматриваются основные характеристики современного института церковно-приходского воскресного образования РПЦ для детей: цели и задачи образовательной деятельности, виды и типы воскресных школ, уровни обучения. Дается характеристика системы воскресного церковно-приходского образования Покровской и Николаевской епархии Саратовской митрополии: перечисляются направления работы отдела религиозного образования и катехизации, приводятся данные по количеству воскресных школ, учащихся, преподавателей. Рассматриваются основные аспекты функционирования одной из воскресных учебно-воспитательных групп Покровской и Николаевской епархии. Представлены результаты социологического исследования отношения родителей к обучению детей в исследуемой православной воскресной школе Покровской и Николаевской епархии.

Ключевые слова: православная воскресная школа; церковно-приходская школа; система религиозного образования Русской Православной Церкви; Покровская и Николаевская епархия (Саратовская митрополия); отношение родителей к религиозному образованию.
\end{abstract}

\title{
Ekaterina Ig. \\ THE ATTITUDE OF PARENTS TOWARDS EDUCATION OF CHILDREN Ufimtseva AT THE ORTHODOX SUNDAY SCHOOL
}

Saratov State National Research University,

83, Astrakhanskaya St., Saratov, 410012, Russia

ufim75@mail.ru

\begin{abstract}
The article is devoted to the analysis of social practices of the modern Orthodox Sunday parochial education in the Russian Orthodox Church (ROC). A brief historiography of the Orthodox Sunday parochial education in Russia. The author discusses the basic characteristics of the Parish Sunday ROC education for children: the goals and objectives of the educational activities, types and forms of Sunday schools, levels of education. The characteristic of the system of Sunday parochial education in intercession Pokrovskaya and Nikolaev diocese of Saratov Archdiocese: it lists the areas of work of the Department of Religious Education and Catechesis, it provides some data on the number of Sunday schools, students, and teachers. The article discusses the basic aspects of the functioning of a Sunday school of Pokrovskaya and Nikolaev diocese. The author presents the results of the survey of parents' attitudes towards the education of children at the Sunday school of Pokrovskaya and Nikolaev diocese.

Keywords: Orthodox Sunday school; parochial school; religious education system of the Russian Orthodox Church; Pokrovskaya and Nikolaev Diocese (Saratov Archdiocese); attitude of parents towards religious education.
\end{abstract}

Изменения отношений церкви и государства, происходящие в российском обществе последние десятилетия, проявляются во всех сферах социальной жизни церкви, в том числе - в сфере образования. Актуальность и значимость исследования особенностей современного 
института православного воскресного образования Русской Православной Церкви (РПЦ) безусловна. В условиях российского общества, характеризующихся последствиями целенаправленного разрушения в советский период традиционных институтов православной социализации (православной семьи, православного быта, системы православного образования), основная роль в православном воспитании детей, в обучении их основам православного вероучения, в формировании у них навыков церковной жизни принадлежит православной воскресной церковно-приходской школе.

Изучение православной воскресной школы в России имеет свои традиции, прежде всего, в области педагогических исследований. Исследователи отмечают, что понятие «воскресная школа» появляется в педагогической литературе в середине XIX века одновременно с массовым распространением самих воскресных школ [1]. В то время к воскресным школам относили образовательные учреждения двух типов: во-первых, церковные школы, предназначенные для конфессионального воспитания детей и юношей; во-вторых, школы, обеспечивающие доступ к получению грамотности людям, не имеющим возможности учиться в обычных школах - «общеобразовательные» воскресные школы. Общим для этих двух категорий воскресных школ было то, что занятия в них проходили по выходным или праздничным дням. Важность воскресных школ в распространении грамотности и религиознонравственном воспитании была отмечена основателями русской педагогики Н.И. Пироговым и К.Д. Ушинским [4]. Об истории создания первых воскресных школ писали дореволюционные исследователи Я.В. Абрамов, Д. Вольфсон, М.Н. Салтыкова, Н.В. Чехов. В советский период опыт воскресных школ рассматривался в работах М.Я. Блинчевской, И.Т. Дронова, П.С. Ткаченко. Современные педагогические исследования воскресной школы посвящены изучению разных аспектов данного феномена: истории становления и развития воскресных школ в России (А.В. Агеева, А.В. Духавнева, Т.В. Лодкина, Л.А. Марченко, Е.А. Никитская); особенностям организации образовательной и воспитательной деятельности воскресных школ (А.В. Агеева, И.В. Архангельская, Г.С. Ващенко, Г.М. Лохонова, А.В. Ляпина); особенностям церковного образования для взрослых (Т.В. Качала, М.В. Попинова); культурно-художественному потенциалу воскресных школ (Н.В. Константинова, И.В. Парамонов, Л.А. Трубникова) [9]. Несмотря на достаточную разработанность проблемы российского церковно-приходского воскресного образования в педагогическом дискурсе, данная проблема относится к неизученным вопросам в современной отечественной социологии.

Современная российская православная воскресная церковно-приходская школа для детей, согласно Положению о деятельности воскресных школ (для детей) Русской Православной Церкви на территории РФ от 2012 г., определяется как религиозная организация Русской Православной Церкви, осуществляющая функцию по обучению религии, а также формированию умений и навыков, необходимых для православного христианина [7]. Она представляет совершенно новый социальный проект по сравнению со своим историческим прототипом. Подразделяются воскресные школы на три типа [8]: воскресная учебновоспитательная группа; воскресная школа, не имеющая статуса юридического лица (являющаяся структурным подразделением религиозной организации Русской Православной Церкви); центр духовно-нравственного воспитания, являющийся самостоятельным юридическим лицом. Учебно-воспитательная деятельность, реализуемая в воскресной школе для детей, включает в себя три ступени: дошкольную (набор детей в возрасте 5-6 лет) с ориентировочным сроком обучения (максимально 2 года); начальную (набор детей в возрасте 7-11 лет) с ориентировочным сроком обучения (максимум 4 года); основную (набор детей в возрасте 12-16 лет) с ориентировочным сроком обучения (максимально 4 года).

В качестве основной цели православной воскресной церковно-приходской школы определяется воспитание детей в системе христианских ценностей и норм поведения, обучение их основам православного вероучения, формирование навыков церковной жизни: участие в богослужениях, церковных Таинствах, а также в социальной и благотворительной деятельности прихода. Как отмечает С.Ю. Дивногорцева «несмотря на то, что основная задача православных воскресных школ - это просвещение и научение Закону Божию детей прихожан, в то же время немаловажной их функцией является воспитание благоговения и христианской нравственности, «культивирование» интереса к богословскому просвещению» [3]. 
Исследование воскресных школ, проведенное А.В. Агеевой, показало, что в зависимости от преобладающего вида деятельности, воскресные школы можно подразделить на: «богословские», «воспитательные», «историко-патриотические», «семейные», «миссионерские», «творческие», «смешанные», «паломнические», «многопрофильные» [2]. Е.А. Никитская, изучая особенности деятельности воскресных школ г. Москвы, выявила, что наиболее типичными для московских школ являются такие направления работы, как: катехизическое (просветительское), социальное служение, культурно-образовательное, военно-спортивное. Исследователь отмечает, что в условиях институциализации российского православного церковноприходского образования самыми острыми проблемами функционирования воскресных школ являются: организационно-педагогические, кадровые, контингентные и материальнотехнические проблемы [5, с. 161-193]. Одной из особенностей современной православной воскресной школы является то, что значимым субъектом образовательного пространства являются родители, чьи дети обучаются в воскресной школе, поэтому необходимо исследовать их мнения, отношения и оценки в отношении православного воскресного образования.

В период с января по май 2015 г. по инициативе отдела религиозного образования и катехизации Покровской и Николаевской епархии на базе воскресной учебно-воспитательной группы «Гефсимания» (г. Энгельс) нами было проведено исследование отношения родителей к обучению детей в воскресной школе ${ }^{1}$. В качестве цели исследования было определено выявление отношения родителей к обучению детей в воскресной учебно-воспитательной группе «Гефсимания» г. Энгельса Покровской и Николаевской епархии. Метод сбора эмпирической информации - индивидуальное

\footnotetext{
1 Пользуясь случаем, хотелось бы сердечно поблагодарить протоиерея Александра Милованова, на момент проведения исследования руководителя отдела религиозного образования и катехизации Покровской и Николаевской епархии и настоятеля СвятоВоскресенского храма г. Энгельса, при котором функционирует воскресная учебно-образовательная группа «Гефсимания», а также педагогический коллектив школы за помощь в проведении социологического исследования, ставшего основой для написания данной научной статьи.
}

стандартизированное анкетирование. Алгоритм формирования выборочной совокупности. Выборочная совокупность формировалась методом основного массива и составила 45 респондентов $\quad(\mathrm{N}=45)$. Методы анализа полученной эмпирической информации: описательный анализ с использованием процентных показателей, простых статистических показателей (моды, медианы, среднего арифметического, стандартного отклонения, стандартизированной ошибки и др.), табличного и графического материала. Представим результаты полученного исследования.

Воскресная учебно-воспитательная группа "Гефсимания" Покровской и Николаевской епархии (2. Энгельс)

Покровская и Николаевская епархия входит в состав Саратовской митрополии. Управление образовательной деятельностью церковных учебных заведений епархии осуществляет отдел религиозного образования и катехизации [6]. Для обеспечения координации деятельности воскресных школ епархии в 2013 году был создан Совет директоров воскресных школ Покровской Епархии, на итоговом заседании которого были озвучены результаты первой аттестации, которую прошли воскресные школы епархии в 2014-2015 учебном году. 32 учебные епархиальные воскресные учебно-воспитательные группы получили сертификаты. Количество обучающихся в них составило 1030 детей и подростков. Преподавательский состав был представлен 131 преподавателем, из которых высшее образование имели - 66\%, 21\% - прошли обучение по Основам православной культуры, 2\% - получили высшее богословское образование.

Одной из первых открывшихся в Покровской и Николаевской епархии воскресных школ была воскресная школа «Гефсимания», которая в соответствие со Стандартом представляет собой воскресную учебно-воспитательную группу. Данная воскресная школа была выбрана нами в качестве объекта социологического исследования, проводившегося в период с января по апрель 2015 г. на тему «Отношение родителей к обучению детей в воскресной православной школе». Исследование проводилось методом анкетирования. Респондентами выступили родители детей, обучающихся в воскресной православной школе «Гефсимания» г. Энгельса $(\mathrm{N}=45)$. Выборочная совокупность формировалась методом основного массива.

Воскресная учебно-воспитательная группа «Гефсимания» не имеет статуса юридического 
лица и является структурным подразделением православного прихода во имя Воскресения Христова, функционирует при СвятоВоскресенском храме г. Покровска (Энгельса) [10]. Школа была образована в сентябре 2000 г. Структуру управления воскресной учебновоспитательной группы «Гефсимания» формируют настоятель прихода, совет школы, педагогический совет, родительский комитет и попечительский совет. В 2014-2015 учебном году состав преподавателей включал 10 человек. Общее количество обучающихся на 2014-2015 г. составило 70 человек, из которых 46 мальчиков и 24 девочки. Весь контингент детей распределен по 5 учебным группам: две дошкольного уровня (возраст 5-6 лет) - первого и второго года обучения и три начального уровня (возраст 7-11 лет) - первого, второго и третьего годов обучения.

В соответствии с текстом Концепции развития воскресной учебно-воспитательной группы «Гефсимания» целью деятельности воскресной школы является «приобщение воспитанников к православной вере и духовной жизни в лоне Русской Православной Церкви». Обучение включает основную и дополнительную части. Основную часть, во-первых, формирует комплекс базовых вероучительных дисциплин: «Введение в Закон Божий», «Основы хорового и церковного пения», «Священная библейская история. Ветхий Завет и Новый Завет», «Устройство православного храма и богослужение», «Церковнославянский язык», «Основы христианской нравственности». Вовторых, основная часть учебно-воспитательной деятельности предусматривает участие детей в литургической жизни церковного прихода. Дополнительную часть учебно-воспитательной деятельности составляют дополнительные занятия по развитию прикладного творчества. Основными направлениями внеклассной деятельности воскресной школы являются: участие в ежегодных мероприятиях воскресных школ Покровской епархии; социальное партнерство; краеведческая деятельность; паломнические поездки. Социальное партнерство предусматривает взаимодействие со светскими образовательными учреждениями.

Социально-демографический профиль родителей детей, обучающихся в воскресной учебно-воспитательной группе "Гефсимания" (2. Энгельс)

Анализ социально-демографических характеристик родителей детей, обучающихся в воскресной учебно-воспитательной группе «Гефсимания», показал, что среди родителей, принявших участие в исследовании, большая часть - 86,7\% - пришлась на женщин. Минимальный возраст опрошенных - 23 года, максимальный - 63 года, средний возраст равен 38 годам. По семейному положению большинство опрошенных состоят в браке - 71,1\% (см. табл. 1 ).

Таблица 1

Распределение опрошенных по семейному положению

Table 1

Distribution of respondents by their marital status

\begin{tabular}{|c|c|c|c|c|c|}
\hline \multicolumn{6}{|c|}{ Семейное положение респондента } \\
\hline & & 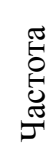 & 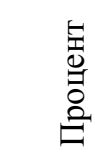 & 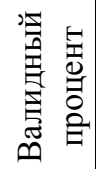 & 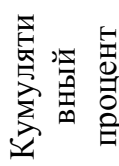 \\
\hline \multirow{6}{*}{ 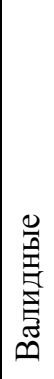 } & Холост/не замужем & 4 & 8,9 & 8,9 & 8,9 \\
\hline & Женат/замужем & 32 & 71,1 & 71,1 & 80,0 \\
\hline & Разведен/разведена & 4 & 8,9 & 8,9 & 88,9 \\
\hline & Вдовец/вдова & 2 & 4,4 & 4,4 & 93,3 \\
\hline & $\begin{array}{l}\text { Проживает в } \\
\text { незарегистрированном } \\
\text { гражданском браке }\end{array}$ & 3 & 6,7 & 6,7 & 100,0 \\
\hline & Итого & 45 & 100,0 & 100,0 & \\
\hline
\end{tabular}

По количеству детей в семье преобладают семьи с двумя детьми $-48,9 \%$, в тоже время почти четверть семей $-22,3 \%$ - имеют более двух детей (см. табл. 2).

Таблица 2

Распределение опрошенных по количеству детей в семье

Table 2

Distribution of respondents by the number of children in the family

\begin{tabular}{|c|c|c|c|c|c|}
\hline \multicolumn{6}{|c|}{ Количество детей респондента в браке } \\
\hline & & Частота & Процент & $\begin{array}{c}\text { Валидный } \\
\text { процент }\end{array}$ & $\begin{array}{c}\text { Кумулятивный } \\
\text { процент }\end{array}$ \\
\hline \multirow{5}{*}{ 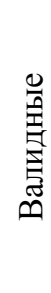 } & 1 & 13 & 28,9 & 28,9 & 28,9 \\
\hline & 2 & 22 & 48,9 & 48,9 & 77,8 \\
\hline & 3 & 7 & 15,6 & 15,6 & 93,3 \\
\hline & $\begin{array}{c}\text { Более } \\
3\end{array}$ & 3 & 6,7 & 6,7 & 100,0 \\
\hline & Итого & 45 & 100,0 & 100,0 & \\
\hline
\end{tabular}

По уровню образования среди опрошенных преобладают родители с высшим образованием $48,9 \%$ (см. табл. 3 ). 
Таблица 3

Распределение опрошенных по уровню образования

Table 3

Distribution of respondents by level of education

\begin{tabular}{|c|c|c|c|c|c|}
\hline \multicolumn{6}{|c|}{ Уровень образования респондента } \\
\hline & & 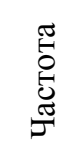 & 氖 & 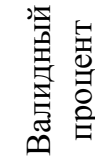 & 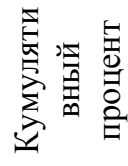 \\
\hline \multirow{5}{*}{ 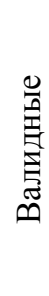 } & Полное среднее & 9 & 20,0 & 20,0 & 20,0 \\
\hline & $\begin{array}{l}\text { Среднее } \\
\text { профессиональное }\end{array}$ & 12 & 26,7 & 26,7 & 46,7 \\
\hline & Неполное высшее & 2 & 4,4 & 4,4 & 51,1 \\
\hline & Высшее & 22 & 48,9 & 48,9 & 100,0 \\
\hline & Итого & 45 & 100,0 & 100,0 & \\
\hline
\end{tabular}

Большинство опрошенных родителей работают - 73,3\% (табл. 4).

По уровню среднего дохода на каждого члена семьи треть опрошенных имеют доход не выше 5000 рублей - 37,8\%. В целом в более половине семей $(64,5 \%)$ средний доход на каждого члена семьи составляет до 10000 рублей (табл. 5).
Таблица 4

Распределение опрошенных по роду занятий

Table 4

Distribution of respondents by occupation

\begin{tabular}{|c|c|c|c|c|c|}
\hline \multicolumn{6}{|c|}{ Род занятий респондента } \\
\hline & & 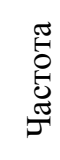 & & 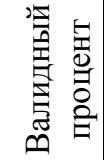 & 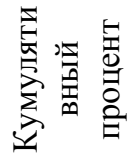 \\
\hline \multirow{8}{*}{ 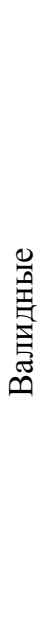 } & Работающий & 33 & 73,3 & 73,3 & 73,3 \\
\hline & $\begin{array}{l}\text { Совмещаю } \\
\text { работу } \\
\text { учебой }\end{array}$ & 1 & 2,2 & 2,2 & 75,6 \\
\hline & $\begin{array}{l}\text { Работающий } \\
\text { пенсионер }\end{array}$ & 2 & 4,4 & 4,4 & 80,0 \\
\hline & $\begin{array}{l}\text { Неработающий } \\
\text { пенсионер }\end{array}$ & 1 & 2,2 & 2,2 & 82,2 \\
\hline & Безработный & 5 & 11,1 & 11,1 & 93,3 \\
\hline & $\begin{array}{l}\text { Нахожусь } \\
\text { декретном } \\
\text { отпуске }\end{array}$ & 2 & 4,4 & 4,4 & 97,8 \\
\hline & Домохозяйка & 1 & 2,2 & 2,2 & 100,0 \\
\hline & Итого & 45 & 100,0 & 100,0 & \\
\hline
\end{tabular}

Таблица 5

Распределение опрошенных по уровню среднего дохода на каждого члена семьи

Table 5

Distribution of respondents by average income per family member

\begin{tabular}{|l|l|c|c|c|c|}
\hline \multicolumn{2}{|c|}{ Уровень среднего дохода на каждого члена семьи респондента } \\
\hline \multirow{5}{*}{ Валидные } & Частота & Процент & $\begin{array}{c}\text { Валидный } \\
\text { процент }\end{array}$ & $\begin{array}{c}\text { Кумулятивный } \\
\text { процент }\end{array}$ \\
\cline { 2 - 6 } & Не выше 5000 рублей & 17 & 37,8 & 38,6 & 38,6 \\
\cline { 2 - 6 } & $5001-10000$ рублей & 12 & 26,7 & 27,3 & 65,9 \\
\cline { 2 - 6 } & $10001-15000$ рублей & 4 & 8,9 & 9,1 & 75,0 \\
\cline { 2 - 6 } & $15001-20000$ рублей & 9 & 20,0 & 20,5 & 95,5 \\
\cline { 2 - 6 } & 20001-25000 рублей & 2 & 4,4 & 4,5 & 100,0 \\
\hline & Итого & 44 & 97,8 & 100,0 & \\
\hline Пропущенные & Затрудняюсь ответить & 1 & 2,2 & & \\
\hline Итого & & 45 & 100,0 & & \\
\hline
\end{tabular}

\section{Степень воцерковленности родителей}

Воцерковленность личности рассматривается нами в аспекте религиозно-конфессиональной социализации, как освоенность личностью и соблюдение ею норм и практик культового (церковного) поведения, характерного для православной религиозной традиции. Степень освоенности личностью норм и практик церковного поведения может быть различной. С нашей точки зрения, она косвенно указывает на намерение личности руководствоваться в повседневной жизни христианскими (православными) нравственными ценностями, то есть последовательно воспроизводить (сохранять) религиозную православную традицию.

Степень воцерковленности родителей детей, обучающихся в воскресной школе, с нашей точки зрения, является, во-первых, фактором родительской мотивации обучения детей в воскресной школе, во-вторых, одним из основных 
факторов

воцерковленности

выявление

детей.

степени

воцерковленности родителей детей, обучающихся в воскресной школе, является необходимым в рамках исследования современных условий воссоздания православного воскресного церковно-приходского образования в России в целом, и нашего исследования, в частности.

Степень воцерковленности родителей определялась нами по модифицированной методике В.Ф. Чесноковой «Индекс воцерковленности» или «В-индекс». Индекс воцерковленности или В-индекс - суммарный показатель степени (уровня) воцерковленности православных христиан. Индекс воцерковленности образован путем группировки данных по шести показателям воцерковленности: «религиозно-конфессиональная

самоидентификация», «частота посещения православного храма», «частота причащения», «регулярность чтения текстов Священного Писания», «форма молитвы», «пост». Показатель «религиозно-конфессиональная самоидентификация» - дополнительный, определяет оценку респондентом собственной религиоз- ности/конфессиональности. Остальные пять показателей - базовые - измеряются по пятибалльной шкале. Данные по ним позволяют разбить весь контингент опрашиваемых на пять групп по степени воцерковленности: группа О (нулевые) - самая слабая степень воцерковленности; группа C (слабовоцерковленные); группа $\mathrm{H}$ (начинающие); группа П (полувоцерковленные); группа Ц (воцерковленные или церковный народ).

Как показал анализ степени воцерковленности родителей учебновоспитательной группы «Гефсимания», 97,8\% опрошенных верят в Бога и 95,6\% признают себя православными. На вопрос «Как часто Вы принимаете участие в церковном богослужении?» треть опрошенных родителей $(33,3 \%)$ ответили, что несколько раз в месяц, треть $(28,9 \%)$ еженедельно, треть $(28,9 \%)$ - несколько раз в год. Таким образом, по участию в богослужении опрошенные родители представляю собой почти равнообъемные группы: воцерковленных, полувоцерковленных, начинающих воцерковление (табл. 6).

Таблица 6

Распределение опрошенных по частоте участия в церковном богослужении

Table 6

Distribution of respondents by attendance of church services

\begin{tabular}{|c|l|c|c|c|c|}
\hline \multicolumn{2}{|c|}{ Частота участия респондента в церковном богослужении } \\
\hline \multirow{2}{*}{} & Частота & Процент & $\begin{array}{c}\text { Валидный } \\
\text { процент }\end{array}$ & $\begin{array}{c}\text { Кумулятивный } \\
\text { процент }\end{array}$ \\
\hline \multirow{3}{*}{ Валидные } & Никогда не участвовал & 2 & $\mathbf{4 , 4}$ & 4,4 & 4,4 \\
\cline { 2 - 6 } & Реже, чем раз в год & 2 & $\mathbf{4 , 4}$ & 4,4 & 8,9 \\
\cline { 2 - 6 } & Один раз, несколько раз в год & 13 & $\mathbf{2 8 , 9}$ & 28,9 & 37,8 \\
\cline { 2 - 6 } & Несколько раз в месяц & 15 & $\mathbf{3 3 , 3}$ & 33,3 & 71,1 \\
\cline { 2 - 6 } & Еженедельно & 13 & $\mathbf{2 8 , 9}$ & 28,9 & 100,0 \\
\cline { 2 - 6 } & Итого & 45 & $\mathbf{1 0 0 , 0}$ & 100,0 & \\
\hline
\end{tabular}

А вот полученные ответы о регулярности исповеди и причастия позволяют несколько изменить представление об уровне воцерковленности родителей. Только около $14 \%$ опрошенных родителей исповедуются и причащаются несколько раз в месяц (воцерковленные), большинство (53,3\%) указали, что принимают участие в этих таинствах один или несколько раз в год (начинающие) (табл. 7 и 8). 
Распределение опрошенных по частоте исповеди

Table 7

Distribution of respondents by frequency of confession

\begin{tabular}{|l|l|c|c|c|c|}
\hline \multicolumn{6}{|c|}{ Частота исповеди респондента } \\
\hline \multirow{3}{*}{ Валидные } & Частота & Процент & $\begin{array}{c}\text { Валидный } \\
\text { процент }\end{array}$ & $\begin{array}{c}\text { Кумулятивный } \\
\text { процент }\end{array}$ \\
\cline { 2 - 6 } & Никогда не участвовал & 6 & $\mathbf{1 3 , 3}$ & 14,3 & 14,3 \\
\cline { 2 - 6 } & Реже, чем раз в год & 4 & $\mathbf{8 , 9}$ & 9,5 & 23,8 \\
\cline { 2 - 6 } & $\begin{array}{l}\text { Один раз, несколько раз в } \\
\text { год }\end{array}$ & 24 & $\mathbf{5 3 , 3}$ & 57,1 & 81,0 \\
\cline { 2 - 6 } & Несколько раз в месяц & 6 & $\mathbf{1 3 , 3}$ & 14,3 & 95,2 \\
\cline { 2 - 6 } & Еженедельно & 1 & $\mathbf{2 , 2}$ & 2,4 & 97,6 \\
\cline { 2 - 6 } & Каждый пост & 1 & $\mathbf{2 , 2}$ & 2,4 & 100,0 \\
\cline { 2 - 6 } & Итого & 42 & $\mathbf{9 3 , 3}$ & 100,0 & \\
\hline Пропущенные & Затрудняюсь ответить & 3 & $\mathbf{6 , 7}$ & & \\
\hline Итого & & 45 & $\mathbf{1 0 0 , 0}$ & & \\
\hline
\end{tabular}

Распределение опрошенных по частоте причастия

Таблица 8

Distribution of respondents by frequency of communion

Table 8

\begin{tabular}{|l|l|c|c|c|c|}
\hline \multicolumn{5}{|c|}{ Частота причастия респондента } \\
\hline \multirow{3}{*}{ Валидные } & Частота & Процент & $\begin{array}{c}\text { Валидный } \\
\text { процент }\end{array}$ & $\begin{array}{c}\text { Кумулятивный } \\
\text { процент }\end{array}$ \\
\cline { 2 - 6 } & Никогда не участвовал & 5 & $\mathbf{1 1 , 1}$ & 11,6 & 11,6 \\
\cline { 2 - 6 } & Реже, чем раз в год & 4 & $\mathbf{8 , 9}$ & 9,3 & 20,9 \\
\cline { 2 - 6 } & $\begin{array}{l}\text { Один раз, несколько раз в } \\
\text { год }\end{array}$ & 24 & $\mathbf{5 3 , 3}$ & 55,8 & 76,7 \\
\cline { 2 - 6 } & Несколько раз в месяц & 8 & $\mathbf{1 7 , 8}$ & 18,6 & 95,3 \\
\cline { 2 - 6 } & Еженедельно & 1 & $\mathbf{2 , 2}$ & 2,3 & 97,7 \\
\cline { 2 - 6 } & Каждый пост & 1 & $\mathbf{2 , 2}$ & 2,3 & 100,0 \\
\cline { 2 - 6 } & Итого & 43 & $\mathbf{9 5 , 6}$ & 100,0 & \\
\hline Пропущенные & Затрудняюсь ответить & 2 & $\mathbf{4 , 4}$ & & \\
\hline Итого & & & $\mathbf{1 0 0 , 0}$ & & \\
\hline
\end{tabular}

$11 \%$ опрошенных родителей ежедневно читают духовно-религиозную литературу (воцерковленные), 33,3\% - регулярно (полувоцерковленные), $40 \%$ - иногда (начинающие). $13,3 \%$ опрошенных родителей читают утренние и вечерние правила, $46,7 \%$ - молятся регулярно (полувоцерковленные), $31,1 \% \quad$ - иногда (начинающие). Таким образом, наибольшую группу среди родителей составляют полувоцерковленные или воцерковляющиеся - в среднем 41,6\%. Вторую по объему составляет группа начинающих воцерковление родителей - в среднем 27,2\%. Воцерковленные родители в среднем составляют $16,8 \%$. На основе полученных данных можно сделать вывод, что основной контингент детей данной воскресной школы составляют дети, чьи родители находятся в процессе воцерковления, как и сами дети. Полученные результаты еще свидетельствуют о том, что в процессе воцерковления основные практики культового поведения осваиваются постепенно, с разной очередностью. Наиболее быстро осваиваемая практика - практика церковного богослужения. Вторая по очередности - практика домашней молитвы. Третья - чтение духовно-религиозной литературы. Наиболее сложными, а потому на более позднем этапе осваиваемые практики - исповедь и причастие. 


\section{Отночение родителей к обучению детей в} воскресной учебно-воспитательной группе "Гефсимания" (2. Энгельс)

Как показали результаты исследования, среди основных мотивов, которыми руководствовались родители при принятии решения о воскресном церковно-приходском образовании своих детей, преобладают религиозные и нравственные, а именно: дать ребенку правильные жизненные ориентиры $(51,1 \%)$, познакомить с основами православного вероучения $(44,4 \%)$, приобщить ребенка к церковной жизни (33,3\%) (рис. 1). Преобладание указанных мотивов свидетельствует о том, что среди опрошенных большую часть составляют родители, желание которых дать своему ребенку церковное образование было не случайным, не спонтанным, а осознанным, целенаправленным и наполненным нравственными и религиозными смыслами. В тоже время, отдельную группу составляют родители, которые привели своих детей в воскресную школу с целью решения их социально-психологических проблем или трудностей (в общей сложности $31,2 \%$ ).

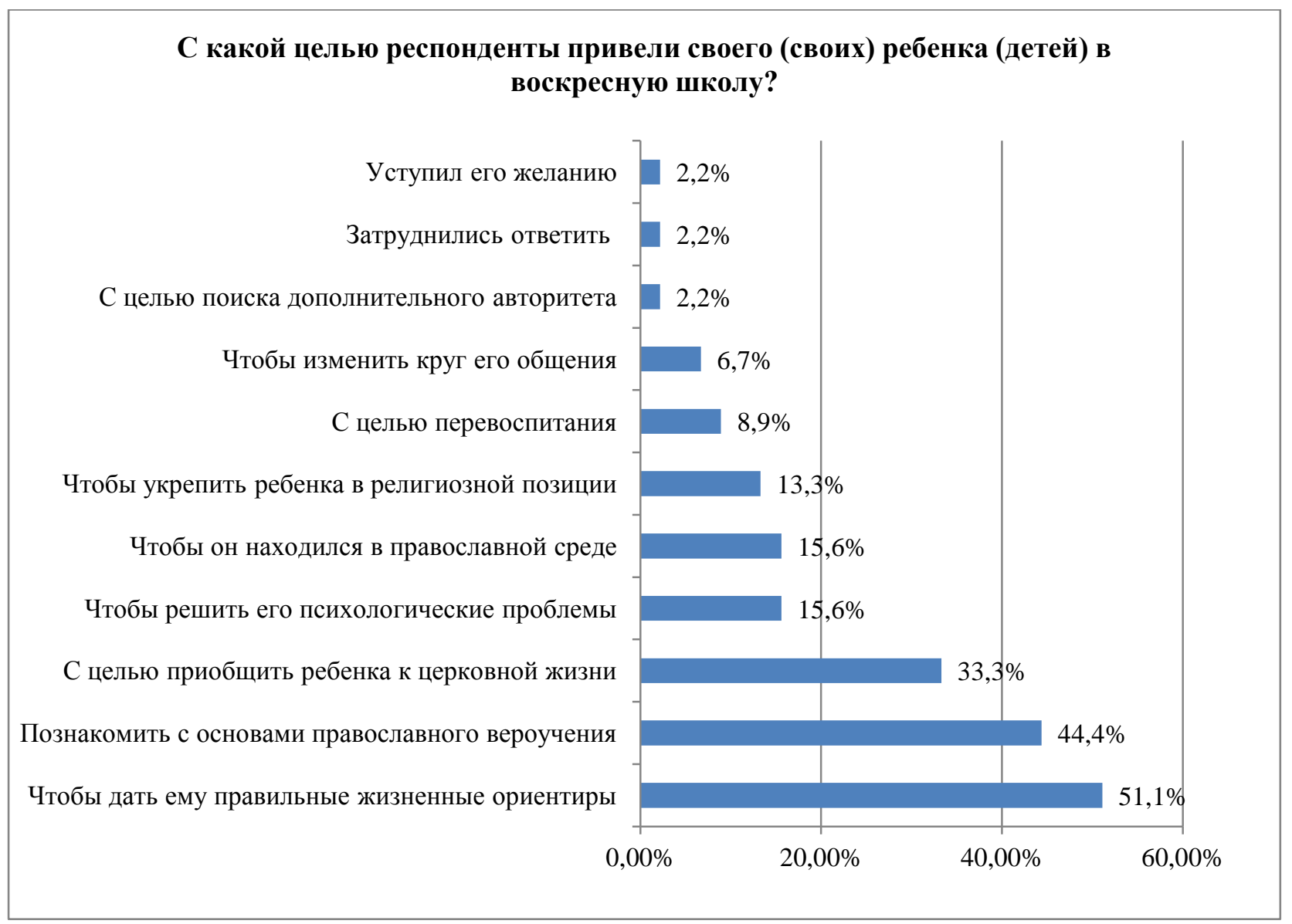

Рис. 1. Основные мотивы родителей, принявших решение о воскресном церковно-приходском образовании своих детей

Fig. 1. Main motives of parents regarding their children education at the Sunday parochial school

$77,8 \%$ родителей указали, что их дети посещают воскресную школу каждую неделю. Чаще всего детей водит мать $(55,6 \%)$ и бабушка $(35,6 \%)$.

Оценивая различные аспекты деятельности учебно-воспитательной группы «Гефсимания» по пятибалльной шкале, родители отметили абсолютную удовлетворенность, во-первых, организацией внеклассных мероприятий $(82,2 \%)$, нравственным поведением учителей $(82,2 \%)$, уровнем духовности и религиозности атмосферы образовательного учреждения $(82,2 \%)$; во-вторых, стоимостью обучения $(80 \%)$, порядком поступления в школу $(80 \%)$, отношением учителей к детям (80\%), режимом работы школы (80\%). Родители наименее удовлетворены работой с родителями $(62,2 \%)$, материальнотехническим оснащением школы $(55,6 \%)$.

Необходимо отметить, что родители сами участвуют в деятельности воскресной школы: 
$57,8 \%$ респондентов участвуют в каждом мероприятии. Всего $8,9 \%$ респондентов признались, что никогда не участвовали в школьных мероприятиях. Основные формы родительского участия: в формах посещения разных мероприятий, организованных школой $71,1 \%$, помощи ребенку при выполнении домашнего задания - $55,6 \%$, участия в субботниках и благоустройстве территории школы $(37,8 \%)$ и чаепитие $(37,8 \%)$ (рисунок 2$)$.

\section{Формы участия в жизнедеятельности воскресной школы}

Работа преподавателем (другое) в этой воскресной школе

Участие в родительских собраниях

Покупка необходимых материалов для школы

Сопровождение в выездных мероприятиях школы

Помощь педагогам в организации трапезы детей

$$
\begin{array}{r}
\text { Чаепитие } \\
\text { Участие в субботниках и благоустройстве } \\
\text { территории школы }
\end{array}
$$

Помощь ребенку при выполнении домашнего задания

Посещение разных мероприятий, организованных школой

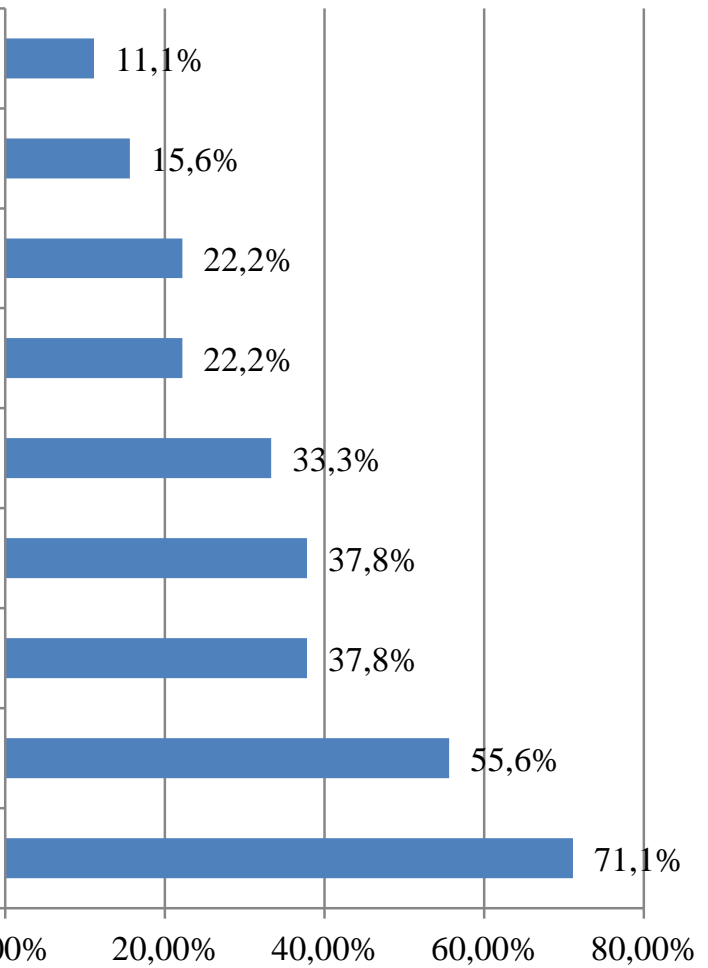

Рис. 2. Формы участия родителей в жизнедеятельности воскресной учебно-воспитательной группе «Гефсимания»

Fig. 2. Forms of participation of parents in the activities of the "Gethsemane" Sunday educational group

Подведем итоги. Рассматривая основные характеристики современных церковноприходских воскресных школ Русской Православной Церкви для детей, можно констатировать, что в новых условиях взаимодействия государства, церкви и общества в российском обществе создается новый институт православного церковно-приходского образования и катехизации. На современном этапе восстановления традиционных церковных институтов православной социализации, церковно-приходские воскресные школы занимают основное место в системе церковного воспитания и образования для мирян. В общецерковных документах РПЦ церковноприходская воскресная школа определяется как основная форма православного воспитания детей и подростков на приходе. В качестве основной функции этого института определяется воцерковление, как религиозная социализации личности в контексте православной традиции с усвоением христианского мировоззрения, ценностей, норм поведения и интеграции в общность православных верующих. В аспекте главной цели современная церковно-приходская воскресная школа сопоставима с первыми, возникавшими в Древней Руси, церковными школами, перед которыми стояла схожая задача наставления в христианской вере переходившего из язычества в христианство древнерусского народа. Схожесть целей древнерусской и современной православной церковной школы, возможно, определяется схожестью нравственнорелигиозного состояния древнерусского народа, принявшего Крещение, и большинства современных православных россиян старших 
поколений, крещенных, но православно не просвещенных, а потому неспособных дать своим детям православное воспитание в семье. В аспекте степени самостоятельности и автономности выбора образовательной программы современная церковно-приходская православная школа в сравнении с церковноприходскими школами дореволюционного периода отличается большей свободой и разнообразием в выборе содержания религиозного обучения. Свободная от государственного вмешательства в управленческий и образовательный процесс современная церковно-приходская школа является подконтрольной епархиальному руководству. Непосредственное управление ею осуществляется руководителем церковного прихода, при котором она функционирует. Если руководит школой духовенство, то преподавательский состав современных церковно-приходских школ формируется преимущественно из воцерковленных светских педагогов. Одним из новых субъектов образовательного процесса церковных школ являются родители. Для родителей современная воскресная школа представляет собой востребованный образовательный проект, в рамках которого родители осуществляют сознательный выбор в направлении религиознонравственного воспитания ребенка. В качестве привлекательных моментов в деятельности воскресных школ родители отмечают организацию внеклассных мероприятий, способствующих формированию нравственных жизненных ориентиров детей; доброжелательный тон в общении с детьми, а также четкую организацию самого образовательного процесса. Вместе с тем, сточки зрения родителей существуют и определенные недостатки в работе воскресной школы, а именно: недостаточное материально-техническое оснащение образовательного процесса и недостаточную степень вовлеченности родителей в образовательно-воспитательную деятельность школы. Отдельное изучение функциональной значимости как педагогов, так и родителей в рамках формирующегося в российском обществе института церковно-приходского воскресного образования - предмет наших будущих исследований.

\section{Литература}

1. Агеева А.В. Церковно-приходские воскресные школы: история возникновения и тенденции развития
// Вестник ПСТГУ. Серия 4: Педагогика. Психология. Вып. 3(18). 2010. С. 58-66.

2. Агеева А.В. Церковно-приходские воскресные школы: история возникновения и тенденции развития // Вестник ПСТГУ. Серия 4: Педагогика. Психология. Вып. 4 (19). 2010. С. 43-55.

3. Дивногорцева С.Ю. Церковный приход как институт религиозного образования // Вера и время. 2011.

URL:

http://www.verav.ru/common/mpublic.php?num=1147 (дата обращения: 12.12.15).

4. Никитская Е.А. Воскресная школа как феномен педагогической действительности. История и современность // Вестник Костромского государственного университета им. Н.А. Некрасова. Серия: Педагогика. Психология, 2008. № 2(9). C. 121-132.

5. Никитская Е.А. Православная воскресная школа как воспитательная организация: социальнопедагогический потенциал. М.: Логос, 2012. 208 с.

6. Отдел религиозного образования и катехизации // Официиальныци сайт Покровской $u$ Николаевской епархии. URL: http://pravpokrov.ru/eparchy/departments/religiouseducation.php (дата обращения: 21.11.2015).

7. Положение о деятельности воскресных школ (для детей) Русской Православной Церкви на территории РФ от 2012 г. // Православное образование. Синодальный отдел религиозного образования и катехизации Русской Православной Церкви. URL: https://pravobraz.ru/polozhenie-o-deyatelnostivoskresnyx-shkol-dlya-detej-russkoj-pravoslavnoj-cerkvina-territorii-rossijskoj-federacii/ (дата обращения: 15.11.2015).

8. Стандарт учебно-воспитательной деятельности, реализуемой в воскресных школах (для детей) Русской Православной Церкви // Православное образование. Синодальный отдел религиозного образования и катехизации Русской Православной Церкви. URL: http://pravobraz.ru/standart-uchebnovospitatelnoj-deyatelnosti-realizuemoj-v-voskresnyxshkolax-russkoj-pravoslavnoj-cerkvi/ (дата обращения: 15.11.2015).

9. Уфимцева Е.И. Воскресная школа в системе религиозного образования Русской Православной Церкви // Известия Саратовского университета. Серия Сочиология. Политология. Т.15. Вып.2. С. 44-52.

10. Уфимцева Е.И. Социальные практики православного воскресного церковно-приходского образования // Известия Саратовского университета. Серия Сочиология. Политология. 2015. Т.15. Вып.3. C. 37-43.

\section{References}

1. Ageeva A. Parochial Sunday schools: the history of the emergence and development trends. VESTNIK PSTGU. Series 4: Pedagogy. Psychology. Vol. 3(18). 2010. Pp. 58-66. 
2. Ageeva A. Parochial Sunday schools: the history of the emergence and development trends. VESTNIK PSTGU. Series 4: Pedagogy. Psychology. Vol. 4(19). 2010. Pp. 43-55.

3. Divnogorceva S.U. Parish Church as an institution of religious education. Faith and time, 2011. URL:

http://www.verav.ru/common/mpublic.php?num=1147

(date of access: December 12, 2015).

4. Nikitskaya E.A. Sunday school as a phenomenon of the pedagogical reality. History and the Present. BULLETIN OF NEKRASOV KOSTROMA STATE UNIVERSITY. Series: Pedagogy. Psychology. 2008. №2(9). Pp. 121-132.

5. Nikitskaya E.A. Orthodox Sunday school as an educational organization: socio-pedagogical potential. Moscow: Logos, 2012. 208 p.

6. Department of Religious Education and Catechesis. Official site of the Pokrovskaya and Nikolaev diocese.

URL:

http://pravpokrov.ru/eparchy/departments/religiouseducation.php (date of access: November 21, 2015).

7. Regulations on the activities of Sunday schools (for children), the Russian Orthodox Church on the territory of the Russian Federation from 2012. Orthodox education. Synodal department of religious education and catechesis of the Russian Orthodox Church. URL: https://pravobraz.ru/polozhenie-o-deyatelnosti-

voskresnyx-shkol-dlya-detej-russkoj-pravoslavnoj-cerkvina-territorii-rossijskoj-federacii/ (date of access: November 15, 2015).

8. Standard of educational activities implemented in Sunday schools (for children), Russian Orthodox Church. Orthodox education. Synodal department of religious education and catechesis of the Russian Orthodox Church. URL: http://pravobraz.ru/standart-uchebno-vospitatelnojdeyatelnosti-realizuemoj-v-voskresnyx-shkolax-russkojpravoslavnoj-cerkvi/ (date of access: November 15, 2015).

9. Ufimtzeva E.I. Sunday school in the religious education system of the Russian Orthodox Church. Izvestiya of Saratov University. New Series. Series: Sociology. Politology. T.15. №2. Pp. 44-52.

10. Ufimtzeva E.I. Social practices of the orthodox Sunday of parochial education. Izvestiya of Saratov University. New Series. Series: Sociology. Politology. T.15. №3. Pp. 37-43.

Уфимцева Екатерина Игоревна, доцент, кандидат социологических наук, Саратовский национальный исследовательский государственный университет им. Н.Г. Чернышевского.

Ekaterina Ig. Ufimtseva, Associate Professor, $\mathrm{PhD}$ in Sociology, Saratov State National Research University 